\title{
モルモット摘出回腸における 収縮薬 $\mathrm{K}$, acetylcholine, histamine, Ba および鎮痤薬 isoproterenol, papaverine の作用機序，とくに Ca との関連
}

\author{
大村一平 \\ 神戸大学医学部薬理学教室*（指導，松本 博教授） \\ （昭和50年12月 10 日[特]）
}

\begin{abstract}
要䄪：モルモット回腸条片を用い，K, acetylcholine (ACh), histamine (His), Ba の各收縮機 序执よび isoproterenol (Iso), papaverine (Pap) の各鎮痤機序を, Ca との関連において, 検 討した．上記 4 収縮薬による収縮の形は， phasic contraction ( $\mathrm{PC}$ ) とこれに続く tonic contraction (TC) よりなる. $\mathrm{K}, \mathrm{ACh}, \mathrm{His}$ の $\mathrm{PC}$ は $\mathrm{Ca}$ 遊離と passive の $\mathrm{Ca}$ influx によっ て起り，BaのPCは Ca 遊離によって起る。一方， K, ACh, His の TC は active の Ca influxによって維持され，Ba の TC は Ca 遊離と active の Ca influx によって維持される. 筋細胞獏の $\mathrm{Ca}$ influx には, $\mathrm{Ca}$ が, (1)最も離れやすい, store, (2)次いで離れやすい store, (3)離れにくい store の区分があり，Kは(1)から，ACh と His は(1)と(2)から，Baは(1)，(2)， (3から，それぞれ，収縮に利用される Ca を遊離させる．Iso および Pap の弛䌅作用に拈よ 活す高K脱分極の影響ならびに K, ACh, Ba および外来 Ca による収縮の形に対する Iso お。 よび Pap の作用を総合して，次の推定を得た．Iso の鎮痓機序は膜の抑制（Ca 遊離および

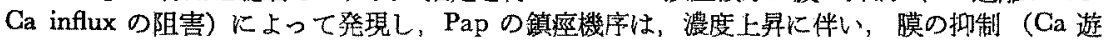
離および Ca influx の阻害）に次いで，筋收縮系の反応を抑制するのによる，濃度作用曲線を 用いて, Iso 拉よび Pap の収縮抑制型式を解析し，この結果（Table 2）について考察した。 Iso および Pap が K, ACh，Ba の PC おょび TC の対数漲度作用曲線を右に平行移動させ るのは, PC および TC の発現に際して起る Ca 動員に対する機能的拮抗によることが示唆 された.
\end{abstract}

\section{緒匐}

平滑筋臟器において，多くの薬物が $\mathrm{Ca}$ の動員（influx または遊離）を介して収縮を起すといら報告があ

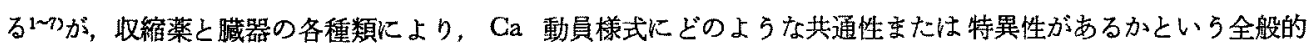
な理解には，まだ知見が不足し，とくに，Ba の収緶機序については見解の不一致がある1,5,8 122. 本研究では， これらの問題点の解明に資するため，モルモット摘出回腸に㧍ける $\mathrm{K}$, acetylcholine (以下, ACh), histamine (以下, His) および Ba の收縮機序を， Ca との関連において，検討した。

一方, 平滑筋蔵器における薬物の弛緩（または鎮座）機序と Ca との関連については，その解析方法の離 かしざのために，收縮機序の場合に此べて，報告が少く13 18)，著しく研究が㧍くれている. 本研究で isoproter-

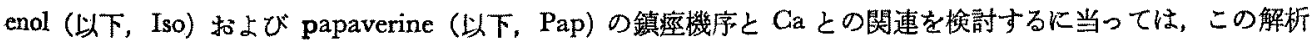
方法の改善に寄与することも一目的とした。

本論文では，「筋収縮系」の用語を，筋收縮要素 (actomyosin) の他に，その収縮に必要なエネルギー代謝も 含む，広い意味で用いることにする。

\section{実験材料および方法}

撗殺した成熟モルモットの回腸（回盲部から 7〜12 cm）上り切り取った長さ約 $1.5 \mathrm{~cm}$ の简形の条片をマグ

\footnotetext{
* 4650 神戸市生田区楠町 7-12
} 


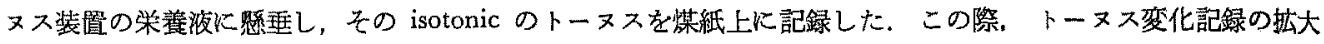
率は約10倍とした、実験開始までには，少くとも90分間栄着液に標本を放置した、栄養淮の温度は $25^{\circ} \mathrm{C}$ とし， たえず気泡を通じた。

栄着液には，Locke 液（蒸留水 11 中K NaCl $9.0 \mathrm{~g}, \mathrm{KCl} 0.42 \mathrm{~g}, \mathrm{CaCl}_{2} 0.24 \mathrm{~g}$, glucose $1.0 \mathrm{~g}, \mathrm{NaHCO}_{3}$ $0.4 \mathrm{~g}$ 含有）を用いた，以後記载する「Ca 除去液」とは，上記の Locke 液から $\mathrm{CaCl}_{2}$ を除去したものである.

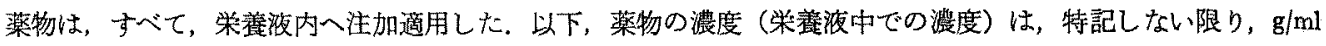
単位で表わす。

使用薬物は，次の通りである.

acetylcholine chloride (東京化成)， barium chloride (和光純薬), calcium chloride (和光純薬)，2,4-dinitrophenol (和光純薬), disodium ethylenediaminetetraacetic acid (EDTA- 2Na) (米山薬品), histamine dihydrochloride (米山薬品), isoproterenol hydrochloride (日研化学), papaverine hydrochloride (藤沢薬品), potassium chloride (和光純薬), sucrose (saccharose) (米山薬品).

\section{実 験 成 績}

\section{I．トーヌスおよび外来 Ca の作用におよぼす栄養液 Ca の除去の影響}

正常栄堆液から Ca 除去液に交換すると，直後に一過性收縮（持続 3 分以内）が起るが，その後のトーヌス 㹥正常栄盖液中と変化がながた。

栄宦液に加えた (外来) $\mathrm{Ca}$ は，正常栄養夜中では通常トーヌスに無影響で，まれに極くかずかの驰緩を起 したが，Ca 除去液に交換後にはつね收縮を起した，この取縮は，外来 $\mathrm{Ca}$ の增量に従って增大し，10〜20m Mで最大となった。

\section{II. 収縮蓝 ( $\mathrm{K}, \mathrm{ACh}, \mathrm{His}, \mathrm{Ba})$ の作用}

1. 収縮の形とこれに拈よぼす代謝阻害括よび策養液の Ca 除去の影響

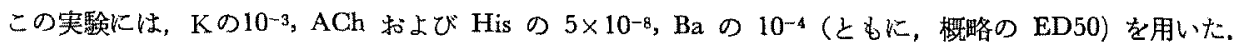
a. 収緶の形

正常栄墥渡中での 4 収縮薬による収縮の形（煤紙上飞記録）は，いずれも，初期のはやい収縮 (phasic con-

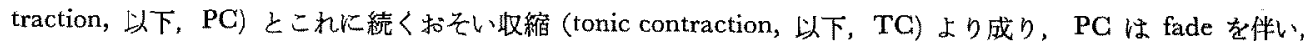
TC は一定の高さで維持された。

$\mathrm{b}$ ，代謝阻害の影響

代謝阻害の目的に，栄塊液への通気遮断（以下，anoxia と呼ら゙）と2,4-dinitrophenol (以下, DNP) の道 用とを行った。

1) anoxia の影響

anoxia は，一過性（持続 3 分以内）の上わい収縮を起しただけで，以後トーヌスに变化を与克なかった．

anoxia Kしてから，Ba では20分間隔，K, ACh，His では15 分間隔で反復適用し，これらの各時点での各 收縮の PC および TC の变化をしらべたところ，Kの TC は，anoxia の $18 \pm 2$ 分後 $(\mathrm{N}=9)$ 上り滅少し始め， $92 \pm 3$ 分後 $(N=9)$ K消失したが，このときKの PC 高は不変であった. ACh の TC は anoxia の58土3分

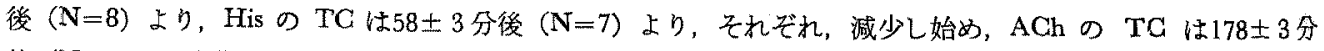

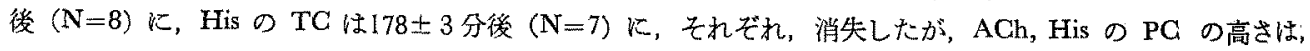

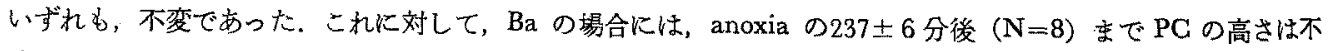
変であったが，このとき TC の高さは $52 \pm 1 \%(\mathrm{~N}=8)$ しか抑制されなかった４収縮薬のいずれの場合にも， anoxia の時間を延長すると，遂には，PCの高さ多減少し始めた。ACh と Ba の場合を Fig. 1 に例示した。

な执，上記した anoxia の影響は，少くともPC の高さが不変の範囲では，可逆的で，通気再開により， 30〜60分でもとの收縮形に回復した

2）DNP の影響

本実駼に用いた濃度の DNPは，直後に濃度依存性の一過性収縮を起したが，6分以内にはもとのトーヌス 

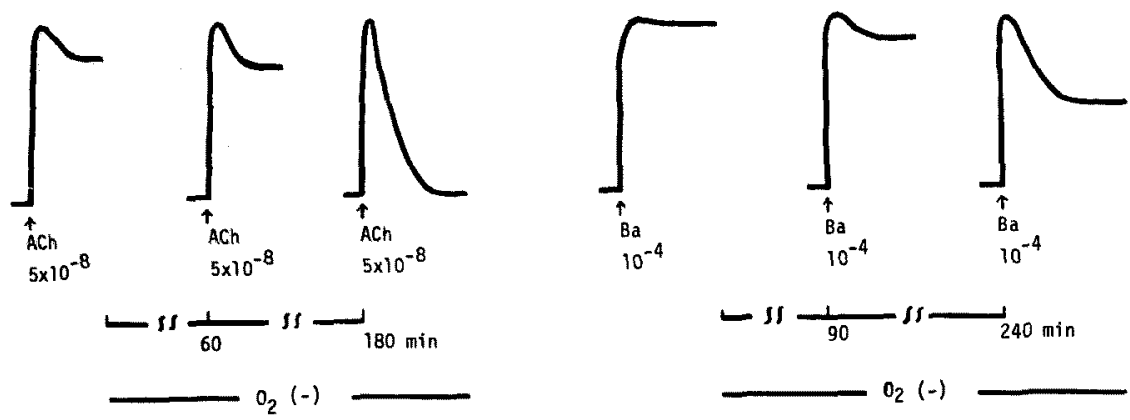

Fig. 1. Influence of anoxia on the shape of contractions induced by $\mathrm{ACh}$ and $\mathrm{Ba}$.

に戻り，以後トーヌスに変化はなかった。

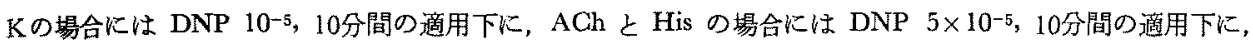
TC が減少し始め，いずれの場合にも，DNP 10-4，10分間の適用下で，TC が消失したが，この時点でも PC の高さ炕変化はなかった，Ba の場合には DNP $5 \times 10^{-5}$ ，20分間の適用下に，TC のみが減少し始めたが， PC

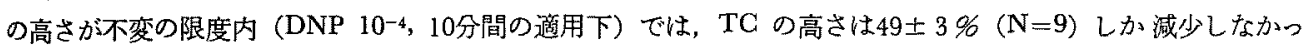
た，各收縮薬に対して，上記以上に DNP の漂度（または適用時間）を增加すると，PC も抑制されれた。

なお，DNP の影響は少くとも，10-4，10分間適用までの範围では，可逆的で，水洗により60分以内除去 された。

c、栄養液の Ca 除去の影響

正常栄養液から $\mathrm{Ca}$ 除去液に交換後短時問（3分）において，Ba の PC の高さは不変，Kの PC は59士

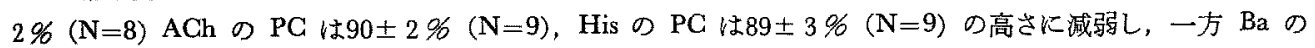

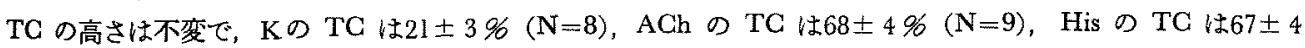
$\%(\mathrm{~N}=9)$ の高さに減少した，この成績に比べて，正常采養液から $0.01 \mathrm{mM}$ EDTA-2 Na 含有の Ca 除去液に 交換の 3 分後では，各収縮薬の $\mathrm{PC}$ の変化は同程度であったが， TC の減少はつよくなり，すなわち，Kの $\mathrm{TC}$

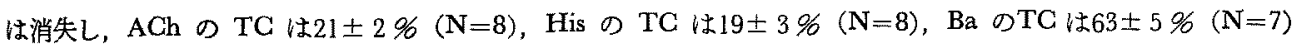
の高さに減少した.

また，Ca 除去液中で各収縮菜の収縮がそれぞれ消失した各時点（後述）で，正常栄養液へ再交換すると， 4 収縮薬のいずれの場合にも，TCの回復が PC の回復よりもずっと速かった。すなわち，正常栄養液への再 交換後，Ba では20分間隔，他の3収縮薬では15分間隔で反復適用し，最初に PC または TC が回復するまでの 時間を仮に回復時間とした場合， K, ACh, His の TC の回復は15分以内, Ba の TC の回復は20分以内であっ

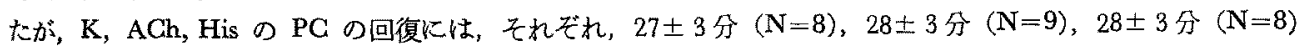
を要し，Ba の PC の回復には，45士 3 分 $(\mathrm{N}=8)$ を要した。

2. Ca 除去夜中における収縮薬の作用消失

正常栄盖莅から Ca 除去液に交换すると，時間の経過に伴い，4収縮薬の ED50 収縮はいずれも漸減し， 遂には消失した，才なわち，Ba では20分間隔，他の3收縮㭗では15分間隔で適用し，最初に収縮が消失するま での時間を仮りに収縮の消失時間とした場合，Kの収縮は $58 \pm 3$ 分 $(\mathrm{N}=8)$ で消失し， ACh の収縮は92 3 分 $(\mathrm{N}=9)$ ，His の収縮は $92 \pm 3$ 分 $(\mathrm{N}=9)$ で，两者はほぼ同時に消失し，Ba の収縮は $158 \pm 4$ 分 $(\mathrm{N}=9)$ で消 失した.いずれの場合にも，TCの消失上りも执くれ PGが消失した。な，ACh の収縮と His の収縮は， 同一標本に标いて，一方が消失した時点では他方む消失することを確かめた。次に，Kの取維の消失時間恃， ACh, His または Ba を途中で1回適用（後水洗）すると，短縮され，ACh または His の収縮の消失時間は， Ba を途中で1回適用（後水洗）すると，短縮された（Table 1).

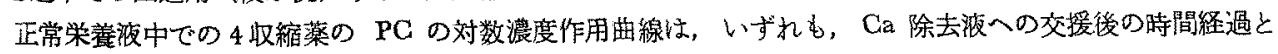
ともに，右と下へ移動し，遂には消失した。 Ba の PC の減弱経過の1 例を Fig. 2 に示した。 
Table 1. Influence of the pretreatment with ACh- and Ba-induced contraction on the time required for disappearance of $\mathrm{K}$ - and $\mathrm{ACh}$-induced contraction in the $\mathrm{Ca}$-free bath solution. Values with and without pretreatment were obtained in the same preparation in each experiment. All values with pretreatment are significantly different from control $(\mathrm{p}<0.05)$.

\begin{tabular}{|c|c|c|c|}
\hline \multirow{2}{*}{ Pretreatment } & \multicolumn{3}{|c|}{ Contraction by } \\
\hline & \multicolumn{2}{|c|}{$\mathrm{K} 10^{-3}$} & ACh $5 \times 10^{-8}$ \\
\hline None (control) & $\begin{array}{c}61 \pm 3.7 \mathrm{~min} \\
(\mathrm{~N}=7)\end{array}$ & $\begin{array}{c}62 \pm 2.3 \text { min } \\
(N=7)\end{array}$ & $\begin{array}{c}91 \pm 3.1 \mathrm{~min} \\
(\mathrm{~N}=7)\end{array}$ \\
\hline ACh $\left(5 \times 10^{-8}\right)$-induced contraction & $\begin{array}{c}47 \pm 2.6 \min \\
(\mathrm{N}=7)\end{array}$ & & \\
\hline $\mathrm{Ba}\left(10^{-4}\right)$-induced contraction & & $\begin{array}{c}41 \pm 3.2 \min \\
(\mathrm{N}=7)\end{array}$ & $\begin{array}{c}73+4.2 \mathrm{~min} \\
(\mathrm{~N}=7)\end{array}$ \\
\hline
\end{tabular}

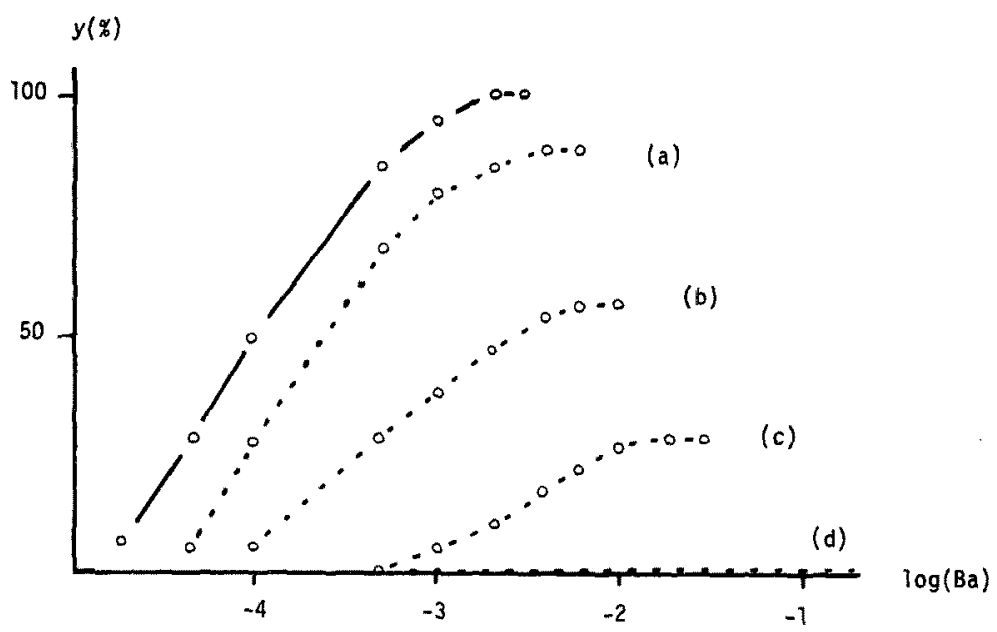

Fig. 2. Modification in the concentration-action curve of $\mathrm{Ba}$ over a lapse of time after exchange of the bath solution from normal to Ca-free the solid line represents the ourve in the normal bath solution and broken lines are those in the Ca-free bath solution. (a), (b) and (c) represent the curves when the contraction by ED50 of K, $\mathrm{ACh}$ and $\mathrm{Ba}$ disappeared respectively and (d) represents the curve at $60 \mathrm{~min}$ after disappearance of the contraction by ED50 of $\mathrm{Ba}$ y $(\%)$ : contraction height.

\section{II. 鎮痓策 (Iso, Pap) の作用}

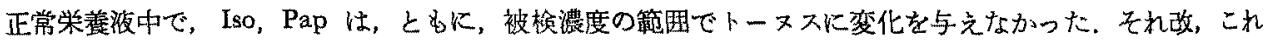
らの弛緩作用は，収縮薬の存在下でしらべた。

1. Iso 扣よび Pap の弛緩作用に扎よぼす高K脱分極の影䍿

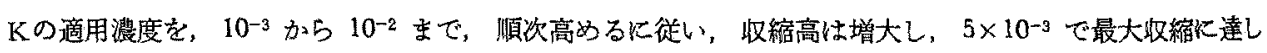
た.これらのK収縮下に特ける Iso よよび Pap の咃瑷作用をしらべた。

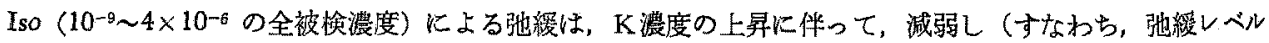
が上昇し)，遂には消失した．例えば，Iso $10^{-7}$ の弛緾はKの $4 \times 10^{-3}$ 収縮下に，Iso $4 \times 10^{-6}$ の弛絠はKの $6 \times 10^{-3}$ 収縮下に，それぞれ消失した. Iso $4 \times 10^{-6}$ による弛綬の模様を Fig. 3 に示した.

Pap の弛緩む，K濃度の上昇に伴って減弱したが，最終的に，Pap の低濃度 $\left(10^{-7} \sim 5 \times 10^{-6}\right)$ の倠䌊作用

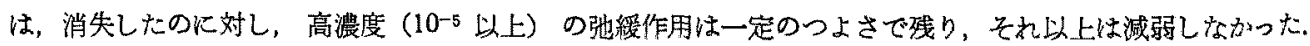




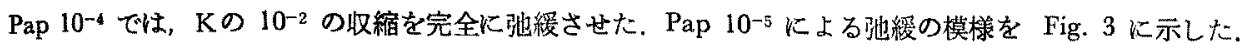
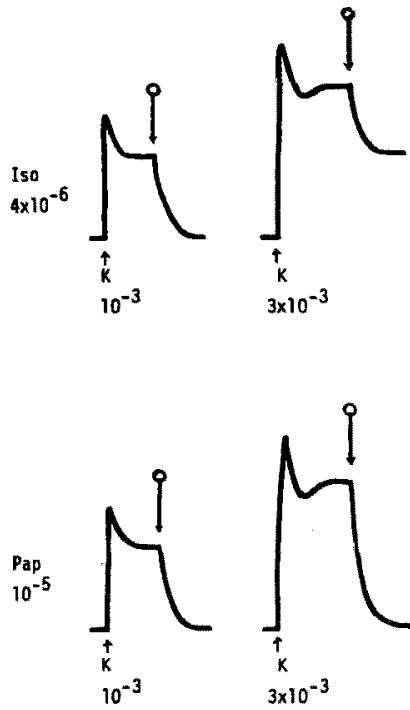
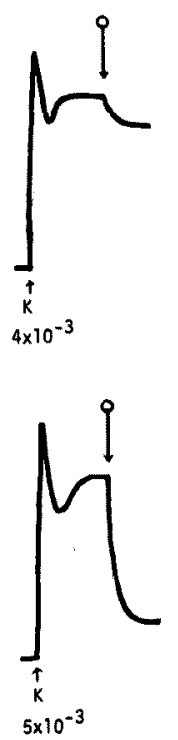
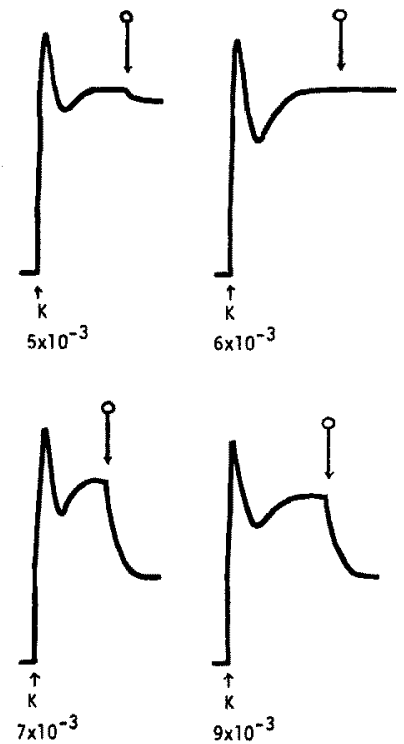

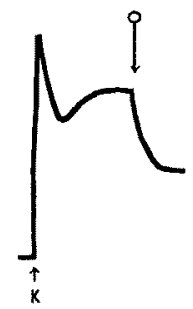

$9 \times 10^{-3}$

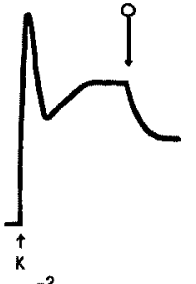

$10^{-2}$

Fig. 3. Relaxing effects of isoproterenol (Iso) and papaverine (Pap) on the contractions by increasing concentrations of $\mathrm{K}$. Q indicates the addition of Iso or Pap.

なお，以上のKの適用は栄養液の浸透圧を高めるので，高K収縮下の Iso または Pap の弛綬作用の減弱が 高浸透王のために起る可能性も考えられるので，この点を吟味するため，前田19の方法に準じて，同じ高浸透王 を示すKと sucrose の影響を比較した結果，K濃度の上昇による Iso 京たは Pap の弛綑作用の減弱は，K增 量によるもので，浸透圧の上昇によるものでないことが示された。

2. K, ACh，His，Ba の各収縮および外来 Ca の収縮の形炕対する Iso および Pap の作用

正常栄養夜中での $\mathrm{K}, \mathrm{ACh}, \mathrm{His}, \mathrm{Ba}$ の各 ED50 収縮の形乩よび Ca 除去液中で ACh 収縮 (ED50) の消 失点での高 $\mathrm{K}\left(6 \times 10^{-3}\right)$ 脱分極下の外来 $\mathrm{Ca}(2.2 \mathrm{mM})$ の収縮の形に対する Iso および Pap の前処置 (10 分前から適用）の影響をしらべた，上記の $\mathrm{Ca}$ 除去液中での外来 $\mathrm{Ca}$ の収縮は二相より成り (Fig. 4) DNP 10-4，10分間の適用下に，第二相は抑制されるが，第一相は抑制されなかったので，第一相は passive の Ca influx, 第二相は active のCa influx とより起ると考㝋られる.

Iso の低濃度 $\left(4 \times 10^{-9}\right)$ および Pap の低濃度 $\left(5 \times 10^{-8}\right)$ は， K, ACh, His Ba の各 PC を抑制せずに, 各 TC のみを抑制し，また外来 Ca の第一相の収縮を抑制せずに，第二相の収縮のみを抑制した。 Iso および

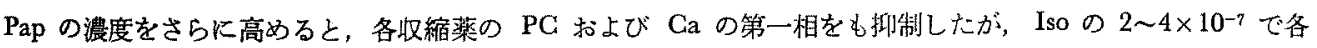
$\mathrm{TC}$ まは $\mathrm{Ca}$ 收縮の第二相が消失したとき，Kの $\mathrm{PC}$ は2 $74 \%(\mathrm{~N}=8)$, ACh の $\mathrm{PC} は 53 \pm 1 \%(\mathrm{~N}=8)$

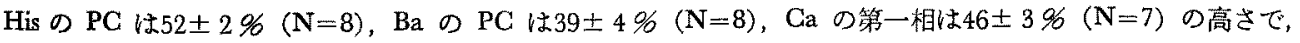

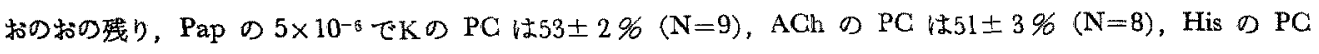

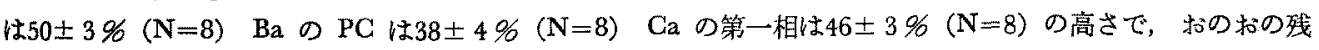
った. ACh と Ca の収縮に対する Pap の影響を Fig. 4 と例示した.

3. 濃度作用曲線からみた鎮痤薬の収縮抑制型式

濃度作用曲線に括ける作用度の示標としては，K, ACh，Ba の場合には，正常栄養液中での PC おょび TC をとり，Ca の昜合には，前記 Ca 除去液中での高 $\mathrm{K}\left(6 \times 10^{-3}\right)$ 脱分極下の第二相の収縮をとった，収縮蒋の 適用法は，Ca 収縮の濃度作用曲線では絮積用量法により，その他の濃度作用曲線で忙単用量法によった。鎮痤 薬红前処置（10分前化適用）法で適用し，鎮痙薬の非存在下 (対照) 之存在下の耐濃度作用曲線の比較は，同一 標本で行った。 

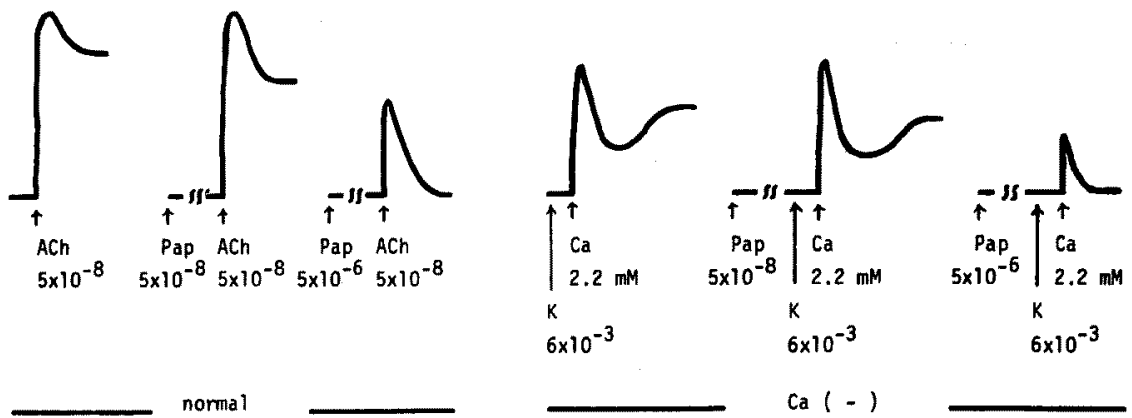

Fig. 4. Influence of papaverine (Pap) on the shape of contractions by $\mathrm{ACh}$ and exogenous $\mathrm{Ca}$.
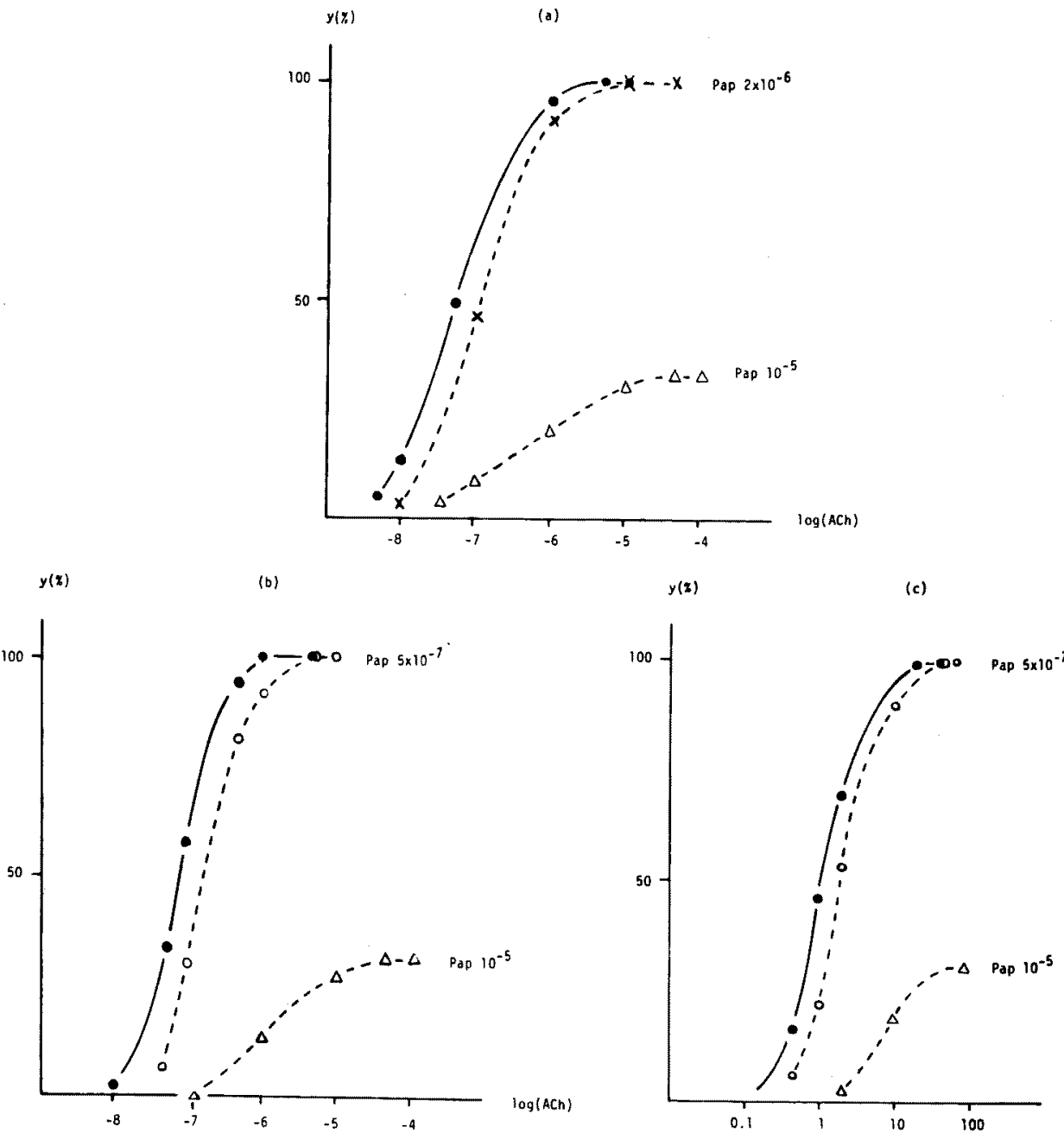

Fig. 5. Influence of papaverine (Pap) on the concentration-action curves of phasic contraction (a) and tonic contraction (b) by ACh in the normal bath solution and on the concentration-action curve of exogenous $\mathrm{Ca}$ (c) in the Ca-free, high K-depolarizing bath solution. $\triangle---\triangle: \operatorname{Pap} 10^{-5}$. 


\section{1）Iso の作用}

Iso の低濃度（対K 10-6 まで，対 ACh $2 \times 10^{-7}$ まで，対 Ba $4 \times 10^{-7}$ まで）は，PG を示標とする各刘 数濃度作用曲線を右に平行移動させ（以下，I 型拮抗 ${ }^{20,21)}$ と呼ぶ），之れ以上の高濃度で忙右上下へ移動させた 以下, 而型拮抗 20,21$)$ と呼ぶ”).

一方，K，ACh，Ba の各 TC 拈よび外来 Ca の収縮に対しては，Iso の同じ濃度範罒 $\left(5 \times 10^{-9} \sim 2 \times 10^{-8}\right)$ でI型拮抗を示し，同じ濃度範眀 $\left(5 \times 10^{-8} \sim 2 \times 10^{-6}\right)$ で而型拮抗への移行を示した。

2) Pap $の$ 作用

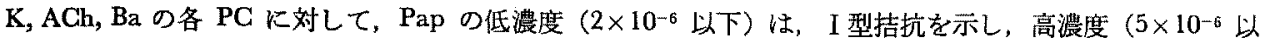
上）は，而型拮抗への移行を示した。

一方，K, ACh, Ba の各 TC と外来 $\mathrm{Ca}$ の収縮に対して，Pap の同じ濃度範囲 $\left(2 \times 10^{-8} \sim 5 \times 10^{-7}\right)$ で I 型拮抗を示し，また，同じ濃度範囲 $\left(10^{-6} \sim 10^{-5}\right)$ で而型拮抗への移行を示した，ACh の PG Ca 収縮に対する Pap の取縮抑制型式を，Fig. 5-a, b, c，に例示した。

以上の各収維に対するIso おょび Pap の拮抗型式を表にまとめると，Table 2 の上5になる。

Table 2. Patterns of antagonisms of isoproterenol and papaverine to the concentration-action (C-A) curves of spasmogens.

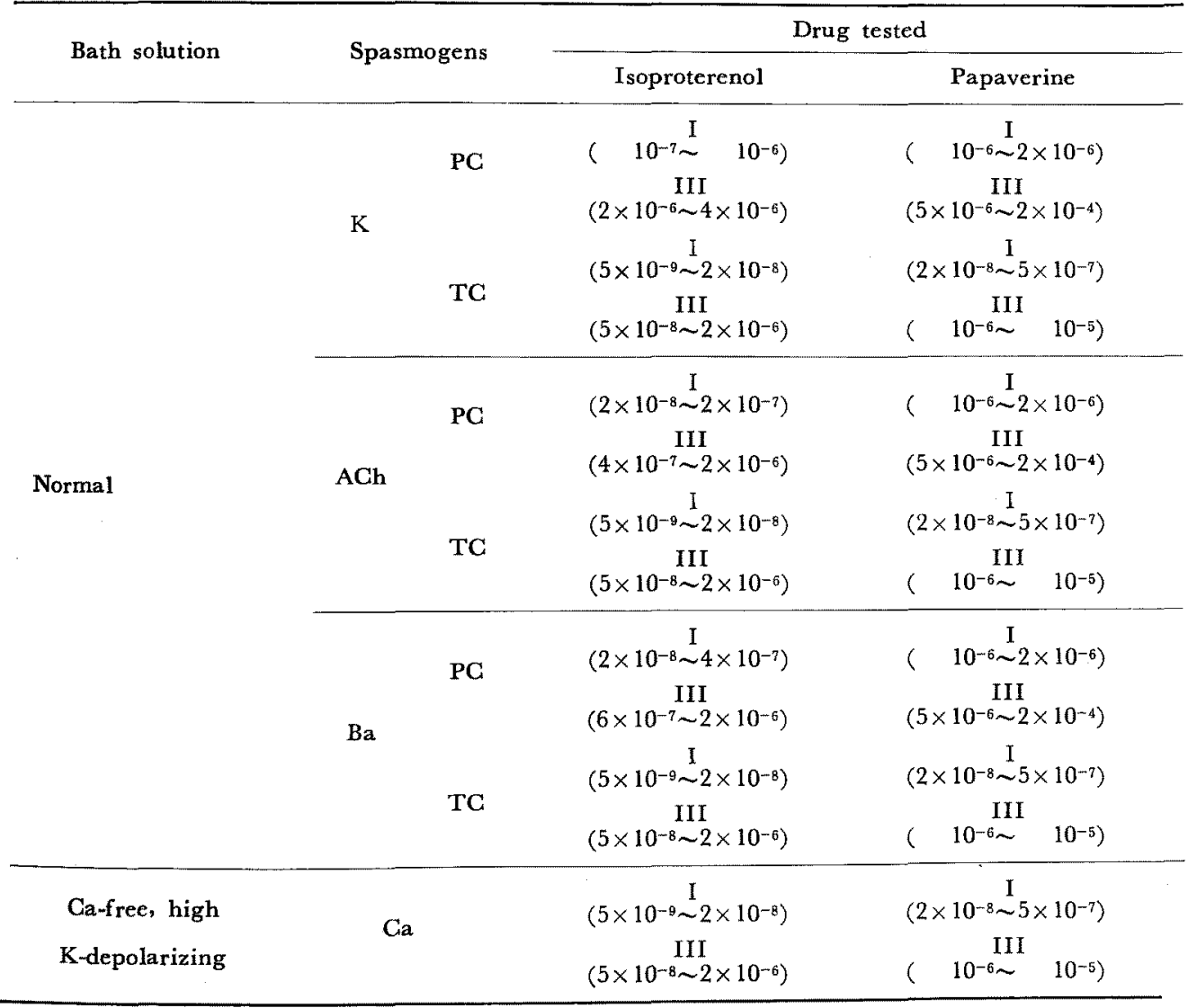

I : type I antagonism (parallel shift to the right of log C-A curve)

III : type III antagonism (shift to the right and downward of $\log$ C-A curve) Figures in parentheses indicate the concentration of drugs tested showing respective patterns of antagonism. 


\section{I 。収縮維 (K, ACh, His, Ba) の作用}

1) 収縮の形とその意義

正常栄養液中に扎いて，4収縮薬（ED50）の示す収縮の形は，いずれも, phasic contraction (PC) とこれ に続く tonic contraction (TC) 上り成り，PC には fade が伴い，TCは一定の高さで維持された。

代謝阻害 (anoxia，DNP) は，K，ACh，His の PC を抑制しない時点で，TC を消失させたが，Ba に対 しては，PCを抑制しない時点で，TC の高ざを約 $50 \%$ しか抑制しなかった。また，正常栄養液から $0.01 \mathrm{mM}$

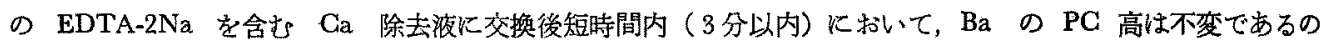
に対L，Kの PC 高は約40\%，ACh, His の PC 高は約 $10 \%$ 減弱し，一方, Kの TC は消失し, ACh, His の TC \&つょく(約 $80 \%$ ）減弱するのK対し，Ba の TC の減弱は比較的軽度（約 $40 \%$ ）であった，一方， Ca 除 去液中で 4 収縮薬の収縮がそれぞれ消失した時点（後述）において, 正常栄養液一再交換すると，ぞの収縮薬の 場合にも，TC の回復がはやく，PC の回復はそれよりずっとおそかった，以上の各所見を総合して，次の推定 を得た（1）4收縮薬の PC はあまりェネルギーを要しない過程で起る．（2） K, ACh, His の PC は， Ca 遊 離と passive の Ca influx Kよって起り，Ba の PC は Ca 遊離によって起る。（3） K, ACh, His の TC は エネルギーを要する active の Ca influx によって維持され，Baの TC は Ca 遊離と active の Ca influx K よって維持される.

上記成績のらち，代謝阻害および栄養液の Ca 除去が示した TC 抑制作用は，モルモット結腸組のK収縮 についての Urakawa ら ${ }^{22)}$ の成績に類似した。

2） $\mathrm{Ca}$ 除去液中での収絤作用の消失

正常栄養液から $\mathrm{Ca}$ 除去液に交換後時間が経つと，4収縮薬（ED50）の収縮はいずれも漸隇し，Kの収縮 は約60分後，ACh と His の収縮は約90分後，Ba の収縮は約160分後に，それぞれ消失した。 また，K収縮の 消失時間は, ACh His または Ba の収縮を先に起させる(後水洗する)ことにより短縮され，ACh，His の収 縮の消失時間は，Ba 収縮を先に起させる(後水洗する)ことにより短縮された。これらの所見から㬳細胞膜の Ca store には, Ca が, (1)最当離れやすい, store, (2)次いで離れやすい store, (3)離れにくい store, の3つの区 分があり，PC の発現に際して，Kは(1)から，ACh と His は(1)と(2)から，Baは(1)，(2)，(3)から，それぞれ Ca を遊離させると推定される，このよらなCa store の区分の存在は，ウサギ大動脈に和ける Hudgins and Weiss の見解 ${ }^{23} \mathrm{~K}$ 一致する．Ca 除去液中で時間が経つと，4収縮薬の濃度作用曲線も，K，ACh (末たは His)，Ba の 順に，いずれも消失し，すなわち，薬物濃度を高めても全く收縮を起し得なくなった。この所見は，上記の各 store が, Ca 除去液中では, 最終的に, いずれも，事実上完全に depleteされることを示唆している.

平滑笳臓器に対する Ba の収縮機序には従来諸説があり，すなわち，(1) Ca 遊離を介する間接作用占,8 -11),

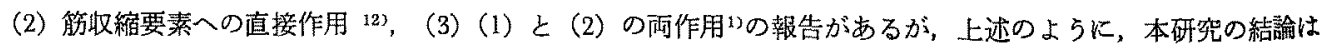
（1）であった．本研究で用いた蔵器では，多分，笳細胞内へのBa の到達量が少いため，Ba のもつ24) actomyosin 収縮作用が現われないのであるらと思われる。

\section{II. 鎮痤菜 (Iso, Pap) の作用}

\section{1）鎮痓薬の能緩作用に括よぼす高 $\mathrm{K}$ 脱分極の影響}

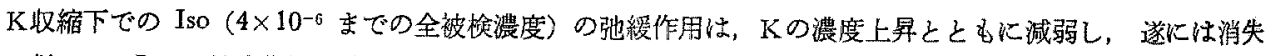
した，従って，Isoの鎮痓作用は筋細胞膜の抑制のみによると考光られる．K收縮下での Pap の弘緩作用もK

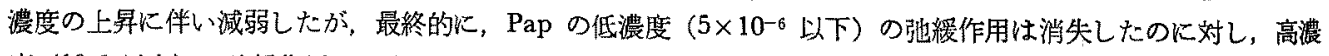
度 $\left(10^{-5}\right.$ 以上) の弛綾作用は一定の強さで残った，従って，Pap の鎮痤作用は，低濃度では膜の抑制によるが， 高濃度 $\left(10^{-5}\right.$ 以上) では，膜以外の㧕制（筋収縮系の反応の抑制）孔加わるためと解される.

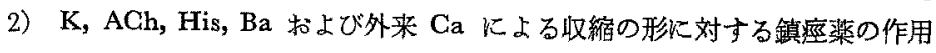

Iso および Pap は, いずれも，低濃度において，K，ACh，His，Ba の PC を抑制せずに(従って，筇収 縮系を抑制せずに）TC のみを抑制したので，active の Ca influx に対する優先的な抑制作用をむっと推定で 
きる. Iso または Pap の濃度をさらに高めると，4収縮薬の PC をる抑制した，Ba の PC は Ca 遊離のみ によって起るので，これらの PC 抑制㙨序に $\mathrm{Ca}$ 遊離の抑制が含まれることは明らかである，一方，Ca 除去， 高K脱分極栄養液中での外来 $\mathrm{Ca}$ の収縮の形は二相より成り，代謝阻害の影響から，第一相は passive の $\mathrm{Ca}$ influx Kより，第二相は active の $\mathrm{Ca}$ influx によって起ると考古られる. Iso 括よび Pap は, いずれも，4 収縮薬の TC のみを抑制する濃度では，外来 $\mathrm{Ca}$ の第二相の収縮のみを抑制し，K, ACh, His の PCをむ抑 制する溇度では，外来 Ca の第一相の収縮をも抑制した，このことから，K，ACh，His の PG 抑制機序には， passive の Ca influx に対する抑制が含まれると考えられる。これらの所見と前述の Iso および Pap の細胞で



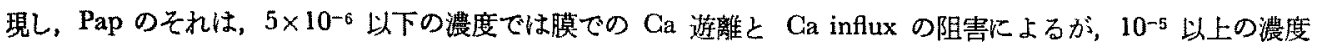
で恃，竻収䋧系をも抑制するためと推定できる。

3）濃度作用曲線からみた鎮穴薬の収縮抑制機序

濃度作用曲線を用いて，正常栄盖液中での $\mathrm{K}, \mathrm{ACh}, \mathrm{Ba} の$ 各 PC および各 TC ならびに Ca 除去，高 $\mathrm{K}$

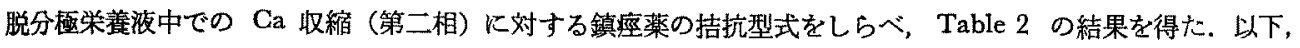
これについて考察する.

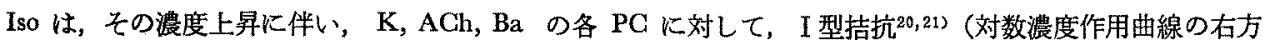
平行移動) からら开型拮抗 ${ }^{20,21)}$ (対数湿度作用曲線の右と下への移動) への䔟行を示した。これらのI 型拮抗の意 味については， $\beta$-receptor に作用するIso がこれら收縮薬の作用過程で競合することはあり得ないので，みか けの競合（偽性競合）であり，PC の発現過程における Ca の動員（既述）に対寸る機能的拮抗 ${ }^{25}$ による思 われる.この機能的拮抗の詳練な機序は不明であるが, Iso が Ca store への Ca のとり込みを促進したり ${ }^{12)}$, 膜を抑制する26,27)ことによって，Ca の収繀的動きを阻害することが考えられる．Iso の高濃度が示す亚型拮抗 については，Iso の膜抑制作用の增強により，㬡性競合関係が破れて，PC の最大収縮が減少するためと思われ る.

Iso は, $\mathrm{K}, \mathrm{ACh}, \mathrm{Ba}$ の各 $\mathrm{TC}$ 拉よび $\mathrm{Ca}$ 収縮に対して同じ濃度範囲で，I 型拮抗から开型拮抗への梦行 を示した。従って，K，ACh，Ba の各 TCに対するI型拮抗は，これらの TC の発現過程に介在する active の Ca influx に対するIso の機能的拮抗によると解され，正型拮抗は偽珄競合関保の破綰によるものであうう.

Pap は, K, ACh, Ba の各 PC に対して, 同じ濃度範围で I 型拮抗から型拮抗への移行を示し，一方, $\mathrm{K}, \mathrm{ACh}, \mathrm{Ba}$ の各 TC 拈よび $\mathrm{Ca}$ 収縮に対しても，同じ濃度範团でI 型拮抗から亚型拮抗への移行を示した。 これらのI型拮抗の意味については，Pap の膜での作用点はまだ解明されていないが，Pap が膜を抑制すると い5報告28 30)があるので，多分，膜での機能的拮抗にもとづく偽珄競合であり，このうち，各 TC に対する機 能的拮抗は，Iso の場合と同様，active の Ca influx 飞対する阻害にもとつくと思われる. Pap の示す亚型拮

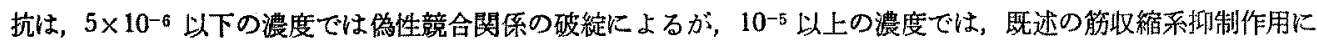
もとづく非競合型阻害の参加によって容易に説明できる，この笳収縮采抑制の機序としては，Pap のもつ酸化 的嵝酸化阻害作用 ${ }^{31}$ にもとづく actomyosin 収縮エネルギーの阻害が最も考克やすい。なお， PC，TCのいず れを示標とした場合にも，Pap によるI型拮抗が ACh，K，Ba に対して同様に現われることから，ACh に対 するI型拮抗を, spare receptor の概念で説明することははとんど不可能である.

本諭文の要旨の一部は，第42回日本薬理学会近畿部会（昭和47年11月18日，京都）および第45回日本薬理学 会近畿部会 (昭和 49 年 6 月 8 日，徳島）に执、てロ演発表した。

稿を終るにあたり，終始御㤵篤なる御指導と御校閲を賜った恩師松本博教授に対し，深甚の謝意を表します。

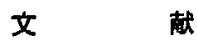

1) Daniel, E. E.: Ann. Rev. Pharmacol. 4, 189 (1964)

2) Hurwirz, L., Jorner, P. D. and von Hagen, S.: Am. J. Physiol. 213, 1299 (1967)

3) Hurwitz, L., Joiner, P. D., von Hagen, S. and Davenport, G. R.: Am. J. Physiol. 216, 215 (1969)

4) Urakawa, N. and Holland, W. C.: Am. J. Physiol. 207, 873 (1964)

5) Karaki, H., IKeda, M. and Urakawa, N.: Japan. J. Pharmacol. 17, 496 (1967) 
6) ImAI, S. and TAKedA, K.: J. Pharmacol, exp. Ther. 156, 557 (1967)

7) Briggs, A. H.: Am. J. Physiol. 203, 849 (1962)

8) Northover, B. J:: Br. J. Pharmacol. 34, 417 (1968)

9) Karaki, H., Ikeda, M. and Urakawa, N.: Japan. J. Pharmacol. 17, 603 (1967)

10) Sperelakis, N.: Fed. Proc. 22, 461 (1963)

11) Ebashr, S. and Endo, M.: Prog. Biophys. Mol. Biol. 18, 123 (1968)

12) Schird, H. O.: Br. J. Pharmacol. 31, 578 (1967)

13) Ferrari, M. and Garpendo, F.: Arch. int. Pharmacodyn. Ther. 174, 223 (1968)

14) Ferrari, M.: J. Pham. Pharmacol. 22, 71 (1970)

15) Simonis, A. M., Ariëns, E. J. and von den Brocke, J. J. W.: J. Pharm. Pharmacol. 23, 107 (1971)

16) Karakt, H., Urakawa, N. and Ikeda, M.: Japan. J. Phamacol. 21, 423 (1966)

17) Takagi, K., Takayanagi, I. and Tomiyama, A.: Japan. J. Pharmacol. 21, 477 (1971)

18) Tashiro, N. and Tomrta, T.: Br. J. Pharmacol. 39, 608 (1970)

19) 前田昌良：日薬理誌 $72 ， 169$ (1976)

20) 松本 博: 生体の科学 6, 113 (1954)

21) Matsumoto, H. and Kumot, T.: Kobe J. Med. Sci. 4, 139 (1958)

22) Urakawa, N., Karaki, H. and Ikeda, M.: Japan. J. Pharmacol. 20, 360 (1970)

23) Hudgins, P. M. and WErss, G. B.: J. Pharmacol, exp. Ther. 159, 91 (1968)

24) Eвashi, S.: Proc. 4th International Congress on Pharmacology, Vol. 1, 32, Edited by Eigenman, R., Schwabe and $\mathrm{Co} .(1970)$

25) ArIËns, E. J.: Molecular Pharmacology, Edited by Ariëns, E. J., Vol. 1, p. 329, Academic Press, New York and London (1964)

26) Somlyo, A. P. and Somlxo, A. V.: Pharmacol. Rev. 22, 249 (1970)

27) Serdes, C. L. and Borr, D. F.: Circulation Res. 28, Suppl. 2, 88 (1970)

28) IMAI, S. and TAKEDA, K.: Nature 213, 509 (1967)

29) Takagi, K., Takayanagi, I., Kubota, K. and Taga, F.: Japan. J. Pharmacol. 20, 398 (1970)

30) Tashiro, N. and Tomita, T.: Br. J. Pharmacol. Chemother. 39, 608 (1970)

31) Santi, R., Ferrari, M. and Contessa, A. R.: Biochem. Biophys. Res. Comm. 11, 156 (1963)

Abstract-Ippei OHMURA (Department of Pharmacology, Kobe University School of Medicine, Ikuta$\mathrm{ku}$, Kobe 650 , Japan). Action mechanisms of the contracting drugs, $\mathrm{K}$, acetylcholine, histamine and $\mathrm{Ba}$ and of the antispasmodics, isoproterenol and papaverine in the isolated guinea pig ileum, particularly in relation to Ca. Folia pharmacol. japon. 72, $201 \sim 210$ (1976).

Shapes of the contractions induced by $\mathrm{K}$, acetylcholine ( $\mathrm{ACh}$ ), histamine and $\mathrm{Ba}$ consisted of the phasic contraction $(\mathrm{PC})$ and the subsequent tonic contraction $(\mathrm{TC})$. PCs by $\mathrm{K}, \mathrm{ACh}$ and histamine are initiated by the release and the passive influx of $\mathrm{Ca}$, whereas that by $\mathrm{Ba}$ is only initiated by the release of $\mathrm{Ca}$. TCs by $\mathrm{K}$, $\mathrm{ACh}$ and histamine are maintained by the active influx of $\mathrm{Ca}$, whereas that by $\mathrm{Ba}$ is maintained by the active influx and the release of $\mathrm{Ca}$. Storage sites of $\mathrm{Ca}$ in the cell membrane of this preparation can be divided into three; the first, the second and the third, which contain the loosely, the less loosely-, and the tightly-bound $\mathrm{Ca}$, respectively. $\mathrm{K}$ releases $\mathrm{Ca}$ to elicit contraction from the first division, $\mathrm{ACh}$ or histamine does so from the first and second divisions, and $\mathrm{Ba}$ does so from all of the three divisions. Based on the infuence of high $\mathrm{K}$ depolarizing bath solution on the relaxations by isoproterenol (Iso) and papaverine (Pap) and the effects of Iso and Pap on the shapes of contractions by $\mathrm{K}, \mathrm{ACh}, \mathrm{Ba}$ and exogenous $\mathrm{Ca}$, the following assumptions were made : antispasmodic action of Iso is produced by inhibition of cell membrane (inhibition of release and influx of $\mathrm{Ca}$ ), whereas that by Pap is due to this inhibition followed by inhibition of the muscle contractile system with the increase of concentrations. The effects of Iso and Pap on the concentration-action curves of the contractions by $\mathrm{K}, \mathrm{ACh}, \mathrm{Ba}$ and exogenous $\mathrm{Ca}$ (Table II) suggest that the parallel shift to the right of the curves of $\mathrm{K}, \mathrm{ACh}$ and $\mathrm{Ba}$ is due to the functional antagonism between the antispasmodics and the mobilization of $\mathrm{Ca}$ produced by the contracting agents. 